\title{
Evaluation of a Retrieved Pyrolithic Reactor to Be Used in Small Farms
}

\author{
Helder José Costa Carozzi ${ }^{1}$, Carlos Eduardo Camargo Nogueira ${ }^{1}$, Thaís Caroline Gazola ${ }^{1}$, \\ Francielle Pareja Schneider ${ }^{1}$, Jair Antonio Cruz Siqueira ${ }^{1} \&$ Diogo Giomo $^{1}$ \\ ${ }^{1}$ Universidade Estadual do Oeste do Paraná, Cascavel, Paraná, Brazil \\ Correspondence: Carlos Eduardo Camargo Nogueira, Universidade Estadual do Oeste do Paraná, Rua \\ Universitária, 2069, Jardim Universitário, Cascavel, Paraná, CEP: 85.819-110, Brazil. Tel: 55-45-3220-7404. \\ E-mail: carlos.nogueira@unioeste.br
}

Received: April 20, 2018

doi:10.5539/jas.v10n7p409

\author{
Accepted: May 27, $2018 \quad$ Online Published: June 15, 2018 \\ URL: https://doi.org/10.5539/jas.v10n7p409
}

\begin{abstract}
The aim of this paper was to evaluate the energy efficiency of a small Generator Motor Group (GMG), driven by internal combustion (fueled with water and gasoline), using pyrolytic reactor technology (GEET). In order to achieve this, the pyrolytic reactor was designed and built, so that when in operation, it obtains extra energy necessary for the pyrolysis process from the thermal energy produced by the combustion of the exhaust gases. In order to determine the efficiency of the small GMG, in conjunction with the GEET, two experiments were carried out: the first one was characterized by the operation and use of the GMG equipped with a carburetor, and when in use it used only ordinary gasoline as fuel. The second experiment was characterized by the insertion of the pyrolytic reactor, which allowed the motor generator group, when in operation, to use water and gasoline as fuel, according to the proportions defined in the methodology. It was possible to verify that the engine, when reaching the voltage near the nominal (115Vac), for the same type and value of load fed, the GEET device presented, during the tests, high and low efficiency results, showing that the experiment is promising, but requires more work and more investigations for correct evaluation of the phenomena observed.
\end{abstract}

Keywords: efficiency, pyrolytic reactor, fuel

\section{Introduction}

Global energy consumption has nearly doubled in the last three decades. In the United States alone, the increase was around $35 \%$. It is estimated that over the next 20 years, energy consumption is expected to rise at nearly a $100 \%$ rate in developing countries. This increase in energy is also occurring in rural areas, due to the implantation of several kinds of agroindustries, which aim to benefit and transform agricultural raw materials into final products with higher commercial value. In many small farms located in Brazil, it is very common the use of Motor Generator Groups (GMG). In this context, a possible solution for improving the efficiency of this energy generation would be using the GMG-with fossil (gasoline) or renewable (ethanol) hydrocarbons-associated with water, as an adjunct fuel element, through the use of the pyrolytic reactor feedback (GEET-Global Environmental Energy Technology) (Hinriches, Kleinback, \& Reis, 2010; Lovins, 2013).

This reactor, during the process of burning the fuel, provides pressure and temperature to the water, breaking its molecule in its fundamental elements: Hydrogen and Oxygen, fuel and oxidizer, in a process of feedback, allowing the burning of the Hydrogen gas along with the conventional fuel (gasoline). The process has the following advantages: a) emission reduction of pollutants, b) lower global warming of the engine, c) increased efficiency of the lubrication system, with consequent increase in the functional durability of the lubricating oil and the internal combustion engine, mainly, d) reduction in fuel consumption (gasoline), for the same work (Martz, 2001; Naudin, 2005).

The general aim of this study was to evaluate the energy efficiency of a GEET device using in a small generator set. Comparison tests of the energy consumption were carried out between the conventional carbureted system and the proposed system. 


\subsection{Engines}

Machines that produce mechanical energy as from other types of energy are called motors (Homa, 2009; Zuffo \& Wolff, 1990). Some types of engines and their conversion processes can be observed in Table 1.

Table 1. Engines regarding to input energy (Homa, 2009)

\begin{tabular}{lll}
\hline Engines in General & & \\
\hline Engine type & Power Supply & Conversion Type \\
\hline Electric & Electricity & Rotational axis \\
Internal Combustion & Hydrocarbon & Rotational axis \\
Reaction & Hydrocarbon & Propulsion-exhaustion of gases under pressure. \\
\hline
\end{tabular}

All engines that transform heat energy into mechanical energy are called thermal motors. Combustion engines can be classified in external combustion engines and internal combustion engines (Homa, 2009).

External thermal combustion engines have the characteristic of burning external fuel to the engine. Their technical advantage is that they can accept any type of fuel, but they have the disadvantage that they cannot be used in certain applications, like aircraft, due to their excessive weight (Homa, 2009; Steam Engine Operation, 2016).

Internal combustion engines have the characteristic of burning the fuel inside the engine. They have technological advantages regarding to the power-to-weight ratio, which gives them advantages in possible aeronautical applications, among other (Homa, 2009). P They can be classified according to the type of movement, in rotary [turbines, gas turbines and Wankel (Albuquerque, 1976)], and alternative (the piston).

In the case of rotary engines, these can be reaction engines, characterized by imparting small air masses at high speeds (Homa, 2009; Antonini, 2000). They may also be of the Wankel Cycle (Albuquerque, 1976), which have as their characteristic constructive parallel axes, in which two bodies, one inside the other, rotate in the same direction around their respective axes, but with distinct speeds, giving rise to chambers with variable volume (Figure 1).

According to Albuquerque (1976), in this type of engine, the parts are subject only to rotary movements, which represent an advantage: this engine is lighter, more compact and it consists of a smaller number of parts if compared to a piston engine.

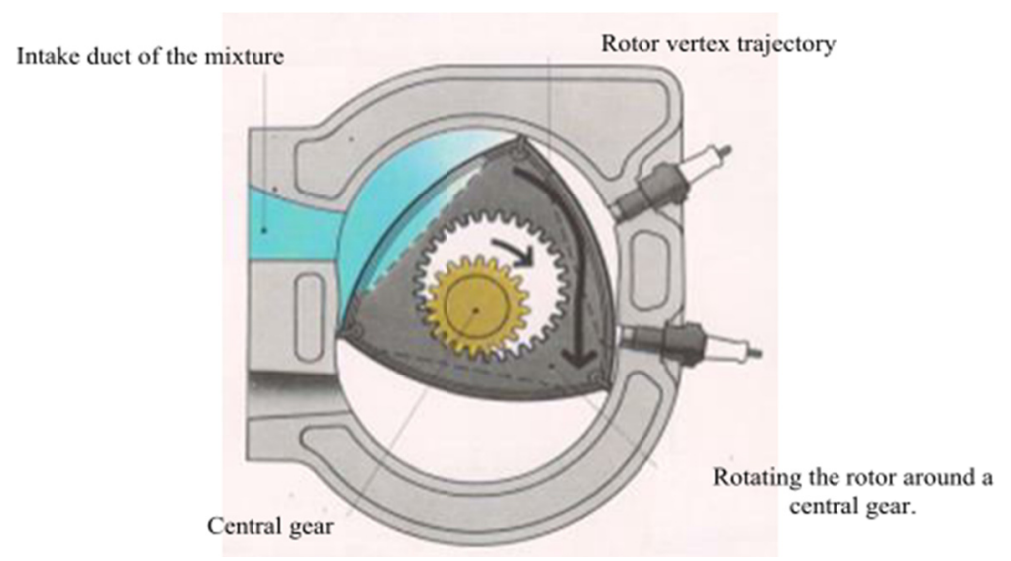

Figure 1. Wankel rotary engine adapted from Albuquerque (1976)

As alternative engines, there are piston engines. This type of engine takes advantage of the energy of burning the fuel inside a cylinder, where the combustion gases drive a piston (Figure 2), whose movement is transformed into rotational movement through a connecting rod attached to a crankshaft (Homa, 2009; Albuquerque, 1976). 


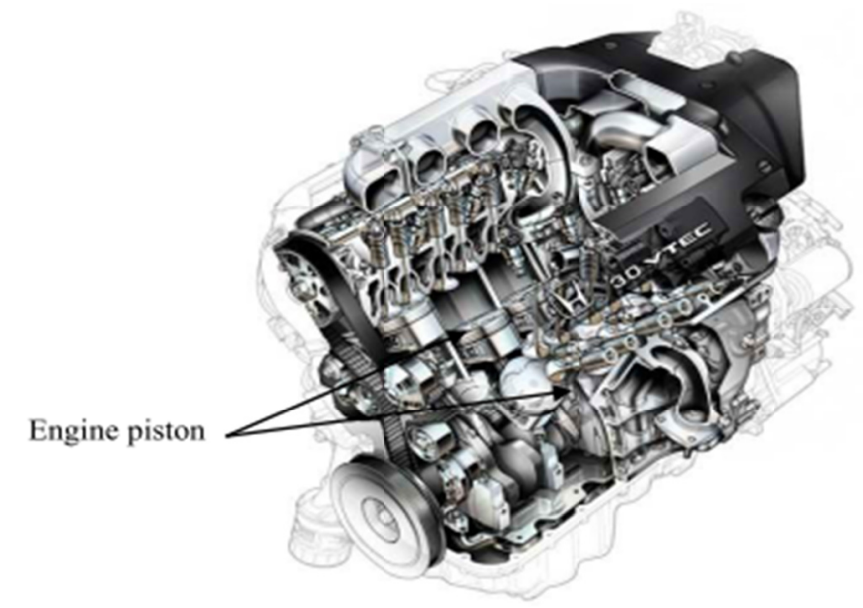

Figure 2. Example of a piston engine-Honda Accord 3.0 VTEC (Daniels \& Daniels, 2007)

The main parts of an internal combustion engine, from the piston type, can be observed in Figure 3 (Albuquerque, 1976).

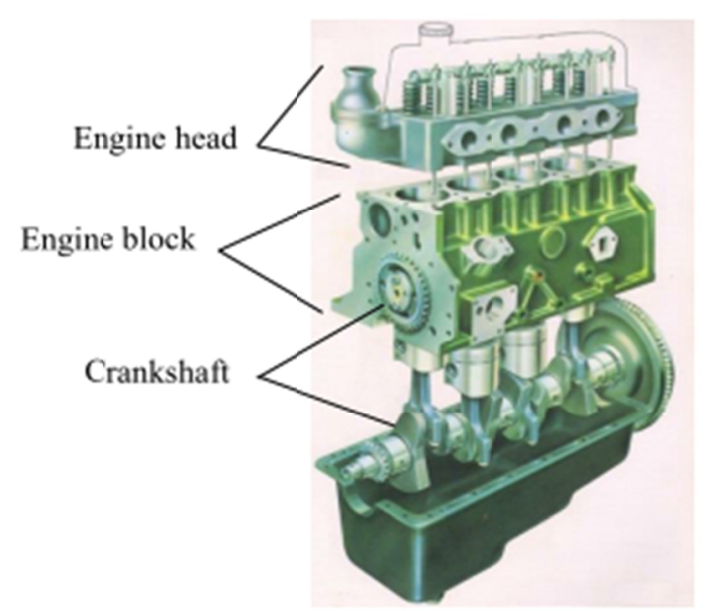

Figure 3. Main parts of a piston engine (Albuquerque, 1976)

Basically, the process by which the transformation of heat energy into mechanical energy occurs can be adequately understood, by means of Figure 4 . 


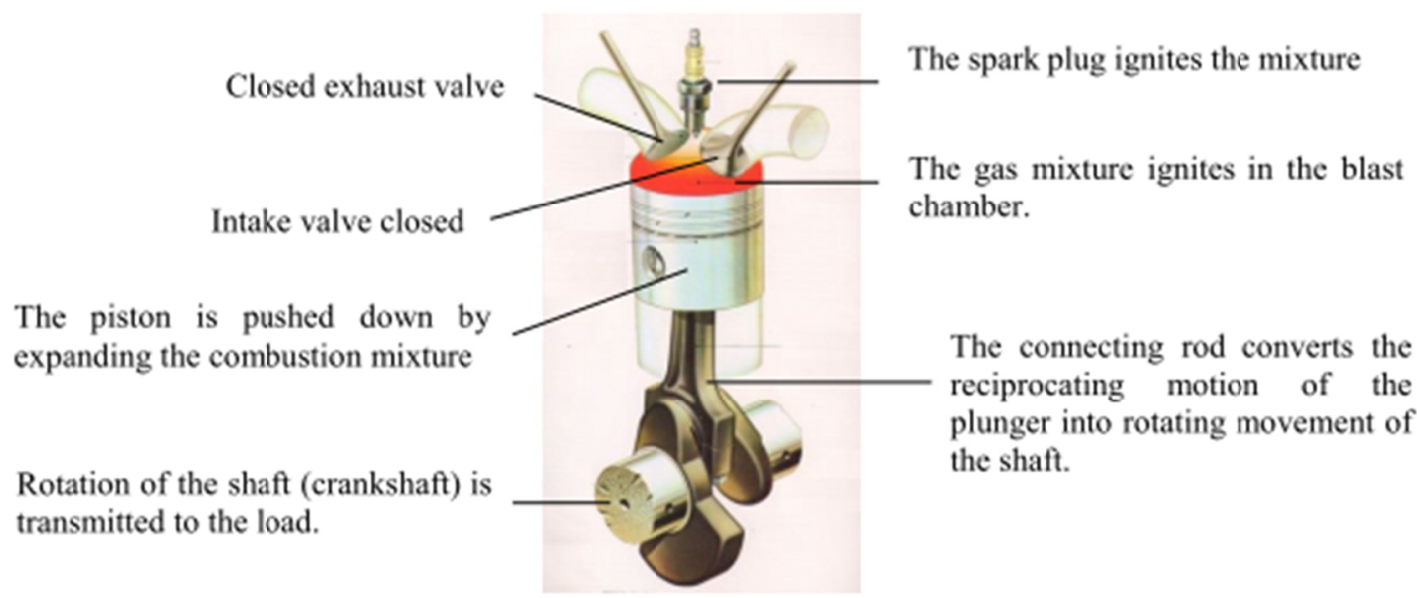

Figure 4. Heat energy transformation in mechanics (Albuquerque, 1976)

The alternative engines have well-defined operating cycles regarding to the explosion process. There are engines called Otto cycle and Diesel cycle.

In a gasoline, alcohol or even Natural Gas Vehicle (NGV) engine, an air-gas (or air-alcohol) or air-gas-alcohol or air-NGV gas mixture is ignited by an electric spark produced by the spark plug ignition. In a Diesel engine there are no spark plugs, and gasoline (or alcohol or NGV) is replaced by diesel oil (Albuquerque, 1976).

The ignition in a diesel engine is caused by compression, which causes the air temperature in the combustion chamber to rise so that it reaches the point of self-ignition of the fuel (Albuquerque, 1976; Hennessy, 2011).

\subsection{Carburetor}

The carburetor is a device that in general provides control and adjust to the amount of air, dosing the gasoline in the correct proportion and, as a result, it adapts the different operational phases of the internal combustion engine: idling, acceleration and working regime, according to the operational necessity. If the air-fuel mixture is not suitable for the desired or desired operation, the engine may stop due to lack or excess fuel (Homa, 2009; Albuquerque, 1976). A variation of the conventional carburetor is the injection carburetor, which is characterized by its working along with a pump, which supplies the device with fuel under pressure. In this case, only the dosing of fuel and oxidizer with the proper amount of air admitted by the engine is left to the carburetor (Homa, 2009; Albuquerque, 1976).

\subsection{Gasoline}

From the fuels currently available, gasoline is the most widely employed nowadays. The daily consumption of gasoline in the United States of America, in 2009, had an average of more than 350 million gallons, which is equivalent to approximately 1324.894 million liters (1US gal $=3.785412 \mathrm{~L}$ ) (Brown \& Holme, 2009). Gasoline is actually a complex blend, and its composition consists of more than 100 different chemicals. Its composition varies with the variation of some parameters, such as the gas content, geographical location and period of the year.

However, its main compounds are hydrocarbons-molecules containing only carbon atoms and hydrogen. Predominantly, such molecules characterize the alkanes, compounds whose atoms are joined by simple bonds. Many of the alkanes in gasoline contain between 6 and 11 carbon atoms, the general formula for any alkane being $\mathrm{C}_{\mathrm{n}} \mathrm{H}_{2 \mathrm{n}+2}$, where $\mathrm{n}$ is an integer.

In the process of burning gasoline in an internal combustion engine, the various compounds present are simultaneously subjected to the combustion process, presenting reactions with oxygen and other constituent elements of atmospheric air (Brown \& Holme, 2009; Henry, 2011). The simplest possible model, for the purpose of analyzing the combustion process, is to take into account a single compound, which is used to represent the gasoline mixture, which is the octane $\mathrm{C}_{8} \mathrm{H}_{18}$.

Considering that gasoline can be represented with reasonable approximation by octane, the description and balancing of the reaction is not so complex. Therefore, taking full combustion into account, octane and oxygen may be evidenced as reactants, and carbon dioxide and water as products (Brown \& Holme, 2009).

Considering that in the United States of America, in many of its States (Brown \& Holme, 2009), tests are 
required to measure the levels of carbon monoxide and hydrocarbon emissions, as well as other compounds in the exhaust process of the engines, the presence, especially of hydrocarbons in the exhaust, indicates that a part of the gasoline passed through the motor cycle without igniting. However, there may be another situation due to the lack of atmospheric air with adequate concentrations of oxygen, giving the conditions to the appearance of incomplete combustion (or burning), having $\mathrm{CO}$ as a byproduct instead of $\mathrm{CO}_{2}$.

The engine temperature is an important parameter to the correct operation of the engine. An appropriately regulated engine ensures that full combustion is maximized, it also limits $\mathrm{CO}$ emissions, and improves gasoline fuel consumption per kilometer.

\subsection{Pyrolysis}

Pyrolysis represents a decomposition reaction by means of heat. In industry, this method is called calcination. It is possible to produce products through this process, such as bio-oil or pyrolytic tar, as well as charcoal, which can be regarded as alternative fuels.

From the pyrolysis of some petroleum refining residues, it is possible to (benefit from them almost entirely) take advantage of them almost in their entirety, resulting in great savings. In this case, the process is also called cracking, where the long chain molecules are broken down into smaller molecules (Fogaça, 2016).

\subsubsection{Pyrolytic Reactor}

The chemical reactor, called the pyrolytic reactor, is the main device applied in the process of industrial pyrolysis. It has three specific areas, namely: drying zone, pyrolysis zone and cooling zone (Fogaça, 2016). The case of water dissociation, by temperature, occurs in two phases (Expressions 1 and 2):

$$
\begin{aligned}
\mathrm{H}_{2} \mathrm{O} & \rightarrow \mathrm{HO}+\mathrm{H} \\
\mathrm{HO} & \rightarrow \mathrm{H}+\mathrm{O}
\end{aligned}
$$

\subsubsection{Pantone Reactor}

According to (Naudin, 2005; Munsey, 2016), the multi-fuel processor is a new technology, attributed to Paul Pantone. The system enables common 4-stroke engines to run on water/hydrocarbon blends, more accurately described as water/gasoline. Under certain conditions of (a specific) regulation of the device and engine, as it is explained (Naudin, 2005), in an Otto cycle engine, all types of fuels are allowed to be burned: petrol, diesel, kerosene, other crude petroleum oils, derived from hydrocarbons, using the multi-fuel processor, which is characterized as an endothermic plasma reactor.

The multi-fuel processor also allows a significant reduction of the pollution generated by the exhaust gas (about $85 \%$ ) compared to a conventional motor (Martz, 2001; Naudin, 2005).

Preliminary tests conducted by industry professionals and other researchers (Martz, 2001; Naudin, 2005) have demonstrated that it is possible to make an internal combustion engine (Otto or Diesel cycle), equipped as the Paul Pantone multi-fuel processor, work properly with a mixture of hydrocarbons (gasoline) at $20 \%$ and water at $80 \%$.

The multi-fuel processor consists basically of three main parts (Naudin, 2005): the connection inlet/exhaust systems, the endothermic reactor (with the magnetic rod and the pyrolytic chamber), and the bubbler. According to (Naudin, 2005), after the installation of the multi-fuel processor (or endothermic plasma reactor), the carburetor and conventional silencer (and catalyst) are no longer required.

In Figure 5, it is possible to observe the schematic drawing of the multi-fuel processor proposed by (Naudin, 2005). 


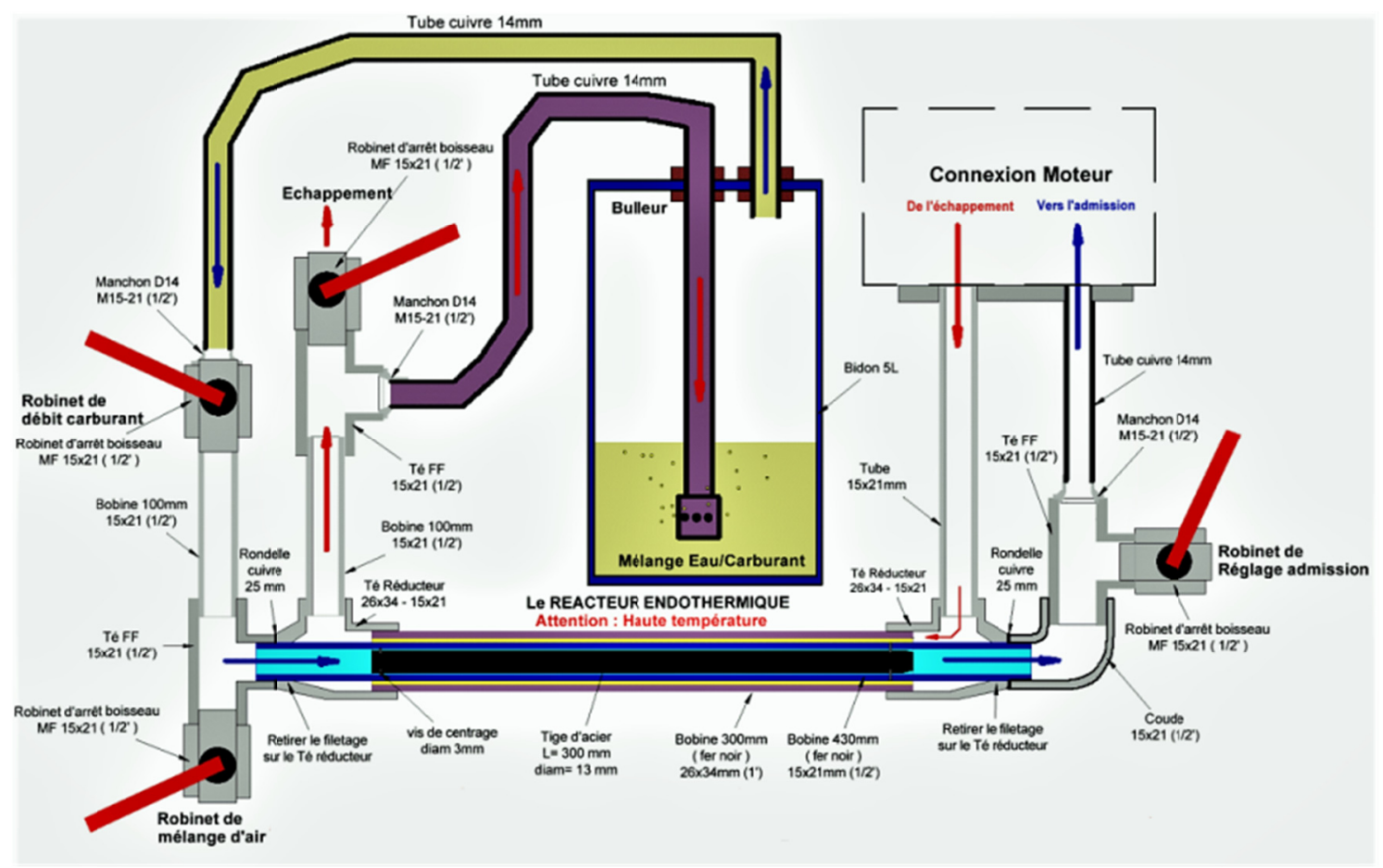

Figure 5. Schematic drawing of the endothermic plasma reactor (Naudin, 2005)

The results obtained with the use of the endothermic plasma, from the measurement of defined points, such as specific consumption, different flows, temperatures, pressures, $\mathrm{H}_{2} / \mathrm{O}_{2}$ gas analysis, resulted in the reduction of pollutants $\mathrm{CO}$ and $\mathrm{HC}$ (unburned fuel hydrocarbon). Pollution levels of carbon gases have been reduced to 40$70 \%$ levels (Martz, 2001).

According to (Martz, 2001), the GEET-Pantone process is a system with plausible potential to mitigate pollution problems arising from the burning of fossil fuels, which could become a benchmark for the market. However, it is clear that further studies-more depth and more detailed, concerning emissions (nitrogen oxides, for example) are necessary to confirm (or not) the $\mathrm{CO}$ extinguishment process, as well as a better process-embedded hardware, with reduction of consumption. At the same time, however, it points to the already observed benefits in terms of heavy metal pollution, once auto-vehicles manufacturers, for decrease levels of pollution, use dangerous and expensive heavy metals in catalytic converters.

\section{Material and Methods}

This work was carried out in the laboratories of the State University of the West of Paraná (UNIOESTE), Cascavel Campus, and in the laboratories of the University Center of the Assis Gurgacz Foundation-FAG, Cascavel Campus.

For the proposed development, we used a generator group of the Toyama brand, model TF1200CXW1, equipped with gasoline engine of $2.5 \mathrm{HP}(\approx 1865$ watts mechanical $)$, tank of 5.0 liters, manual starting, maximum power of $1.2 \mathrm{kVA}$, nominal power of $0.95 \mathrm{kVA}, 110$ volts, in alternating current $(60 \mathrm{~Hz})$, single phase (Figure 6).

The Otto cycle engine, which is part of the generator motor group, is equipped with the OHV (Over Head Valve) system which, according to (Toyama, 2016), is economical, with low fuel consumption, fast and easy starting. 


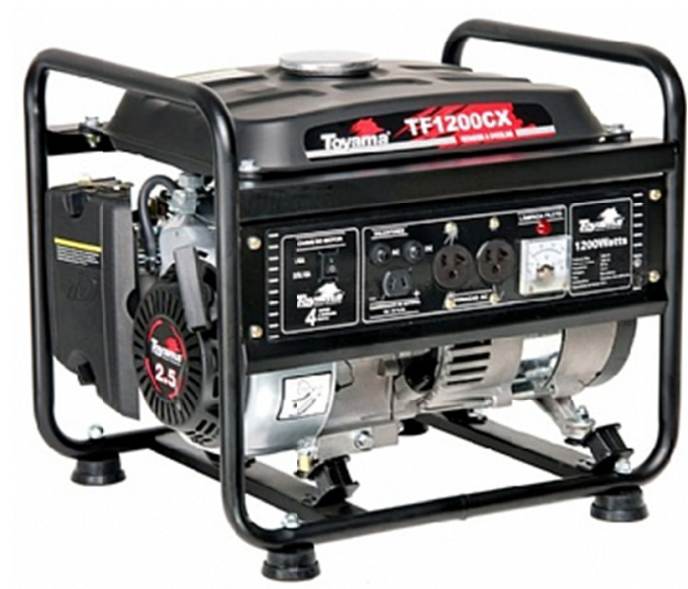

Figure 6. GMG Toyama-model TF1200CXW1 (Toyama, 2016)

A GEET-Pantone reactor was also built to be applied in this same motor generator group. The constructive aspects are next detailed:

\subsection{GEET-Pantone Reactor, or Multi-Fuel Processor or Endothermic Plasma Reactor}

Figure 7 shows the structural schematic design of the main constituent parts of the GEET-Pantone reactor.

The device is composed of two galvanized cylinders (Items 1 and 2 of Figure 7), in a coaxial arrangement, that is, one inside the other. The inner cylinder (Item 2 of Figure 7) has a 1/2 standard thread at each end, one side having a length of $60 \mathrm{~mm}$ (Item 8 of Figure 7) and the other side having a length of $70 \mathrm{~mm}$ (Item 9 of Figure 7). This tube forms the pyrolytic chamber, whose total length is $695 \mathrm{~mm}$, with $15 \mathrm{~mm}$ internal diameter and $22 \mathrm{~mm}$ external diameter. The outer cylinder (Item 1 of Figure 7) has a standard 1 hydraulic thread with $25 \mathrm{~mm}$ of longitudinal length at each end (Items 13 and 16 of Figure 7), which is a steel tube $550 \mathrm{~mm}$ long, $26 \mathrm{~mm}$ of internal diameter and $34 \mathrm{~mm}$ of external diameter.

The assembly of the two cylinders (Items 1 and 2 of Figure 7) in a coaxial arrangement is accomplished by using a 1 to $1 / 2$ reducer sleeve (Items 6 and 7 of Figure 7) with standard internal thread of 1/2 and 1, applied at each end of the cylinders in question.

Item 4 of Figure 7 represents the GEET-Pantone connection duct to the GMG engine exhaust duct, constituting a standard galvanized tube for $1 / 2$ pipe with a $25 \mathrm{~mm}$ longitudinal length (Item 10 of Figure 7) and $100 \mathrm{~mm}$ of total longitudinal length. This duct has an elbow of $90^{\circ}$ (Item 20 of Figure 7) of 1/2, which allows the union with the pipe of 1/2 of diameter (Item 21 of Figure 7), $25 \mathrm{~mm}$ of longitudinal length (Item 22 of Figure 7). At the end of this barrel (Item 21 of Figure 7) the flange (Item 23 of Figure 7) is welded, transversely and inclined at approximately $30^{\circ}$ for rigid coupling of the GEET-Pantone to the exhaust duct of the GMG. Furthermore, Items 3 and 5 of Figure 7 relate to the exhaust pipes which replace the original exhaust and silencer of the GMG, and allow the insertion of the exhaust return control devices to the water and gasoline mixture contained in the reservoir/bubbler GEET-Pantone, and of the fresh air for the admission intake of the GMG system.

The Items 14, 15, 17, 18, 19, 24 and 25 of Figure 7 relate to the final assembly of the structure, characterized by the soldering of the components to guarantee the tightness of the assembly, avoiding possible leaks, especially of the gases resulting from the burning of the fuel. 


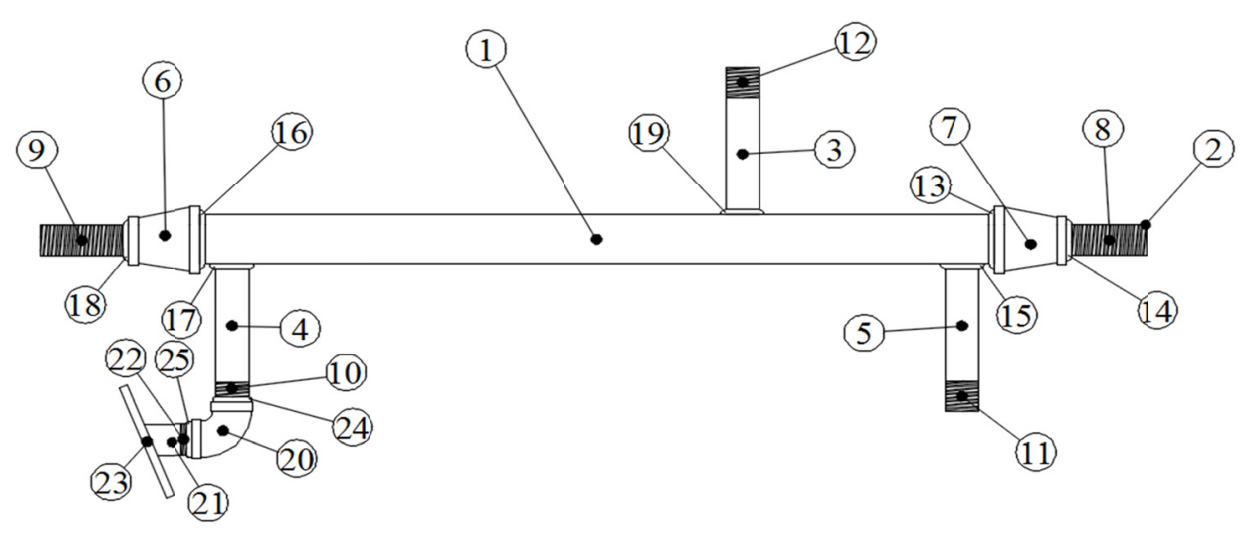

Figure 7. Structural schematic drawing GEET-Pantone

The bubbler is characterized by a graduated glass vessel $(800 \mathrm{ml})$, which allows the mixing of water and fuel in the appropriate proportions, determined by the methodology applied, and allows closing the return circuit of part of the flue gases, creating the constant mixing of gasoline with water, characterizing bubbling proportional to the volume and speed with which gases enter the vessel (Figure 8).

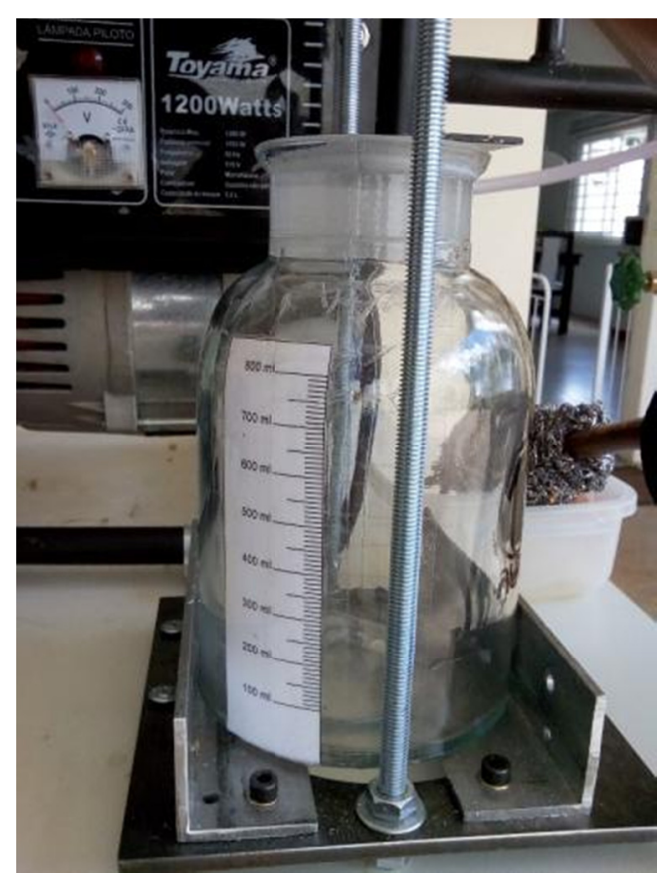

Figure 8. Mixing vessel and bubbler

The principle of operation of the multi-fuel processor consists of a self-induced plasma generator. He considers that a plasma arc, in systems of transforming waste into energy, causes the incoming waste stream to be reduced to its elementary components (broken molecules). The multi-fuel processor is supposedly capable of reaching a plasma state at a much lower temperature, and that is why an internal combustion engine with the multi-fuel processor, proposed by Paul Pantone, could work with the most unusual fuels such as gasoline and water, just having hydrocarbons in its structural chain, such as gasoline, ethanol, diesel, among others (Martz, 2001; Kouropoulos, 1998). All these fuels are only converted into the same final product, the synthesis gas, characterized by combustion, with some ease, in the combustion chamber of the engine. There are also some very unusual aspects of an engine running with an endothermic plasma reactor, where the operating time has to be adjusted, since an implosion (controlled detonation of fuel) replaces the explosive event (Munsey, 2016). 
The flow of hot gas from the engine exhaust flows through the outside of the reactor (between the inner wall of the outer tube or cylinder) with a strong kinetic energy, which contributes to raise the temperature very high in the steel bar-which in this case, acts as a heat accumulator contained in the pyrolytic chamber.

The gases from exhaust, due to burning fuel/oxidizing, internal to the cylinder of the engine, are guided by external pipelines to the reactor (hydraulic flexible hose of $1 / 2$, for high pressure and high temperature with stainless steel mesh) and penetrate in the bubbler, containing the water/hydrocarbon mixture. The vapor of the mixture, in turn, is strongly drawn by the vacuum created by the inlet of the engine (opening of the intake valve and vacuum caused by the downward movement of the piston in the combustion chamber), and is pushed by the pressure from the exhaust. The kinetic energy of steam is considerably increased by the reduction of the diameter on the pyrolytic chamber, which features a circular cross section area of approximately $43.4 \mathrm{~mm}^{2}$. This combined effect of high temperature and increasing kinetic energy of decomposition produces a thermochemical (molecular breakdown) from the mixing of water/hydrocarbons, making it possible to obtain higher yielding fuel.

\subsection{Equipment Used for Performing the Tests}

For the realization of the tests were used the following equipment (FAG and UNIOESTE):

a) Portable Digital Anemometer Model-AN-10-Mark-ICEL.

b) Thermohigrometer-Mark Incoterm-model 7666.02.0.00.

c) Digital Multimeter-Mark Minipa-model ET-1100A.

d) Pliers ammeter-model 266 Clamp Meter.

e) Digital Multimeter and Pliers ammeter-Mark Worker.

f) Digital tachometer-Mark Instrutemp-Model TTAC-7200.

g) Digital Infrared Thermometer with Laser Mira-Mark Fluke-Model 59MAX.

h) Portable Digital Thermometer-model TD800D-Mark ICEL.

i) Precision weighing scale-Mark Quanta-model QTBB-1000G.

j) Table weighing scale WH-B11.

k) Graduated test tube-100 ml-polypropylene base-Mark PHOX.

1) Chronometer-Mark NAUTIKA-NTK-model PROCRON I.

\subsection{Methodology}

\subsubsection{Scenario 1: Original Carburetor Test}

The first scenario was characterized by the use of the original carburetor (without the filter support, to determine the correct positions of the choke butterfly), as well as gasoline (73\% pure gasoline/27\% anhydrous alcohol), additive not (ANP, 2016).

Before each test, the following reference data were recorded:

a) Local (city, state and country);

b) Address (street address, number, neighborhood, postal code and additional information);

c) Date (day, month and year) of the test;

d) Hours (hours and minutes) of the performance of the test determined with chronometer-Mark NAUTIKA-NTK, model PROCRON I;

e) Geographical coordinates of the test site using the Google Earth Pro (2017);

f) Altitude in relation to sea level, through the program Google Earth Pro (2017);

g) Ambient temperature $\left({ }^{\circ} \mathrm{C}\right)$, near the test site (thermohigrometer-Mark Incoterm-model 7666.02.0.00);

h) Relative humidity (\%), near the test site (thermohigrometer-Mark Incoterm-model 7666.02.0.00);

i) Confirmation of the atmospheric pressure check, based on the measured altitude (Item $f$ ) and measured temperature (Item g) through the online MIDÉ (2017) meter;

j) Fuel volume in ml (graduated test tube-100 ml-polypropylene base-Mark PHOX);

k) Mass of fuel (g), using weighing scale in redundancy (Precision weighing scale-Mark Quanta-model 
QTBB-1000G on top of Table weighing scale WH-B11), both zeroed (tare) already considering the mass of the graduated test tube (Item j);

1) Volume ( $\mathrm{ml}$ ) of the crankcase oil, using the rod of the GMG (Generator Motor Group) itself-observing the maximum and minimum points inscribed in it;

m) Visual (color) and tactile (viscosity) verification of crankcase oil characteristics;

n) Temperature $\left({ }^{\circ} \mathrm{C}\right)$ of the resistive load bulb filament, characterized by halogen lamps with tungsten filaments (W), inert gas and iodine (Digital Infrared Thermometer with Laser Mira-Mark Fluke-Model 59MAX);

o) External temperature $\left({ }^{\circ} \mathrm{C}\right)$ of the valve cover (Digital Infrared Thermometer with Laser Mira-Mark Fluke-Model 59MAX);

p) External temperature $\left({ }^{\circ} \mathrm{C}\right)$ of the heat (Digital Infrared Thermometer with Laser Mira-Mark Fluke-Model 59MAX);

q) External temperature $\left({ }^{\circ} \mathrm{C}\right)$ of spark plug ceramics (Digital Infrared Thermometer with Laser Mira-Mark Fluke-Model 59MAX);

r) External temperature $\left({ }^{\circ} \mathrm{C}\right)$ of the float bowl of carburetor (Digital Infrared Thermometer with Laser Mira-Mark Fluke-Model 59MAX);

s) External exhaust duct temperature $\left({ }^{\circ} \mathrm{C}\right.$ )-head/exhaust interface (Digital Infrared Thermometer with Laser Mira-Mark Fluke-Model 59MAX);

t) External exhaust temperature $\left({ }^{\circ} \mathrm{C}\right)$ (Digital Infrared Thermometer with Laser Mira-Mark Fluke-Model 59MAX);

u) External temperature $\left({ }^{\circ} \mathrm{C}\right)$ of the alternator housing (Digital Infrared Thermometer with Laser Mira-Mark Fluke-Model 59MAX);

v) Temperature $\left({ }^{\circ} \mathrm{C}\right)$ of the mass of the fuel at the initial time of the test (Portable Digital Thermometer-model TD800D-Mark ICEL).

Figure 9 presents a schematic drawing of Scenario 1, demonstrating the main aspects of the proposed configuration.

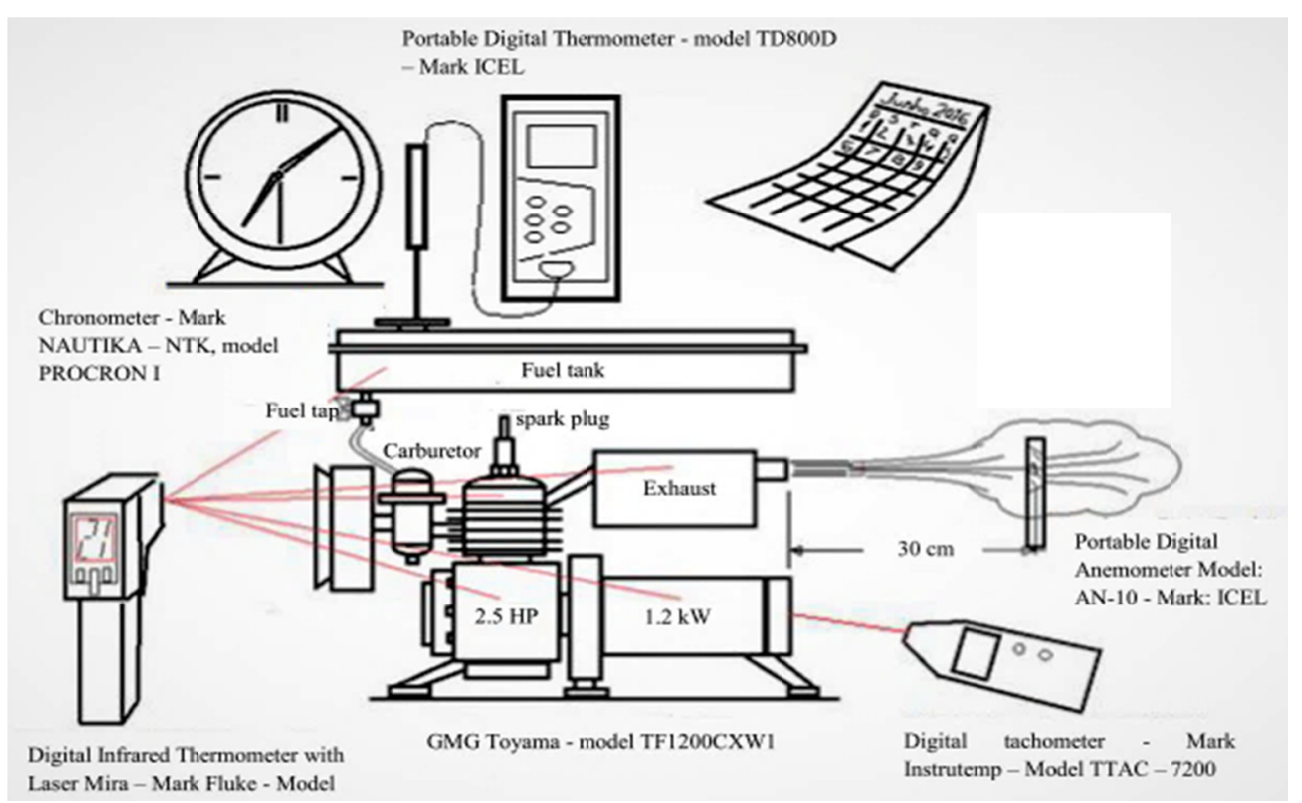

Figure 9. Schematic drawing of Scenario 1: GMG Toyama test with original carburetor

One (1) experiment was performed for nominal load of $70 \mathrm{~W}, 1$ (one) test for nominal load of $140 \mathrm{~W}, 1$ (one) test for nominal load of $210 \mathrm{~W}$ and 1 (one) test for nominal load of $560 \mathrm{~W}$. The following variables were measured, every minute, in a total of 5 minutes per test: 
a) External temperature $\left({ }^{\circ} \mathrm{C}\right)$ of head/valve cover;

b) External temperature $\left({ }^{\circ} \mathrm{C}\right)$ of head engine;

c) External temperature $\left({ }^{\circ} \mathrm{C}\right)$ of spark plug ceramics;

d) External temperature $\left({ }^{\circ} \mathrm{C}\right)$ of the float bowl of the carburetor;

e) External temperature $\left({ }^{\circ} \mathrm{C}\right)$ of the exhaust duct of the head/exhaust interface;

f) External temperature $\left({ }^{\circ} \mathrm{C}\right)$ of the exhaust pipe;

g) External temperature $\left({ }^{\circ} \mathrm{C}\right)$ of the alternator housing, measured in the three constituent structures;

h) Exhaust gas velocity using a portable digital anemometer model: AN-10-mark: ICEL, placed $30 \mathrm{~cm}$ away from the exhaust gas outlet;

i) Stability of rotation and uncharged power, using an digital tachometer-mark Instrutemp-model TTAC-7200;

j) Variation of the electrical parameters using, simultaneously, the instruments: digital multimeter-mark Minipa-model ET-1100A, pliers ammeter-model 266 clamp meter and digital multimeter and pliers ammeter-mark Worker;

k) Fuel consumption at the nominal speed of $3600 \mathrm{rpm}$, using the time spent (in seconds) to consume $60 \mathrm{ml}$ of fuel, since the original tank was replaced by a graduated element with a maximum capacity of $60 \mathrm{ml}$.

The general configuration with load, using the original GMG Toyama carburetor, can be seen in Figure 10. The fuel tank, although closed at the top, has a sigh to maintain proper fuel flow, preventing pressure difference and consequent reduction of fuel supply, according to the needs of the GMG during the test.

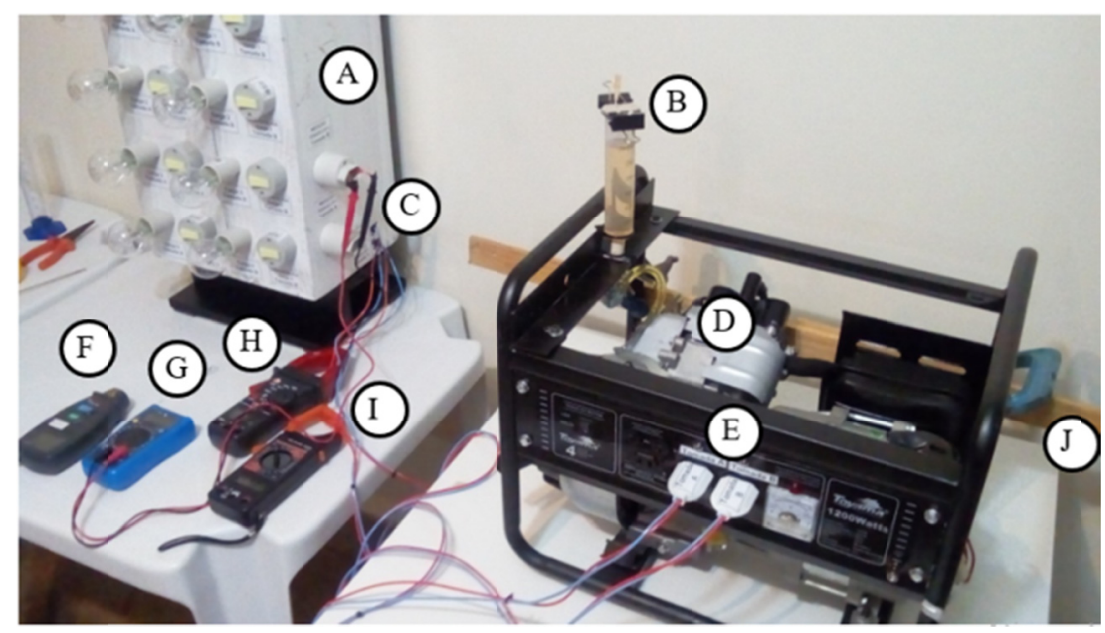

Figure 10. Test setup with GMG load

Note. (A) Test bulbs; (B) Fuel tank with $1 \mathrm{ml}$ resolution and total capacity of $60 \mathrm{ml}$; (C) Voltage measurement point-A and B sockets-from GMG; (D) Generator Motor Group-GMG-Toyama-model TF1200CXW1; (E) Power outlet-A and B, from GMG; (F) Digital tachometer-Mark Instrutemp-Model TTAC-7200; (G) Digital Multimeter-Mark Minipa-model ET-1100A; (H) Digital Multimeter and Pliers ammeter-Mark Worker; (I) Pliers ammeter-model 266 Clamp Meter; (J) Support and extension of the speed meter of the Portable Digital Anemometer Model: AN-10-Mark: ICEL.

\subsubsection{Scenario 2: GEET-Pantone Reactor Test}

The second scenario was characterized by the replacement of the original carburetor by the GEET-Pantone Reactor, using gasoline ( $73 \%$ pure gasoline $/ 27 \%$ anhydrous alcohol), not added together with water treated by the local sanitation company, mixed in the mixing vessel/bubbler, at a ratio of $25 / 75$ (twenty-five percent gasoline and seventy-five percent water), according (Martz, 2001; Naudin, 2005).

Before carrying out the tests, the same reference data already presented in Scenario 1 were noted. Figure 11 shows a schematic drawing, showing the main configuration aspects that were proposed and executed in Scenario 2. 


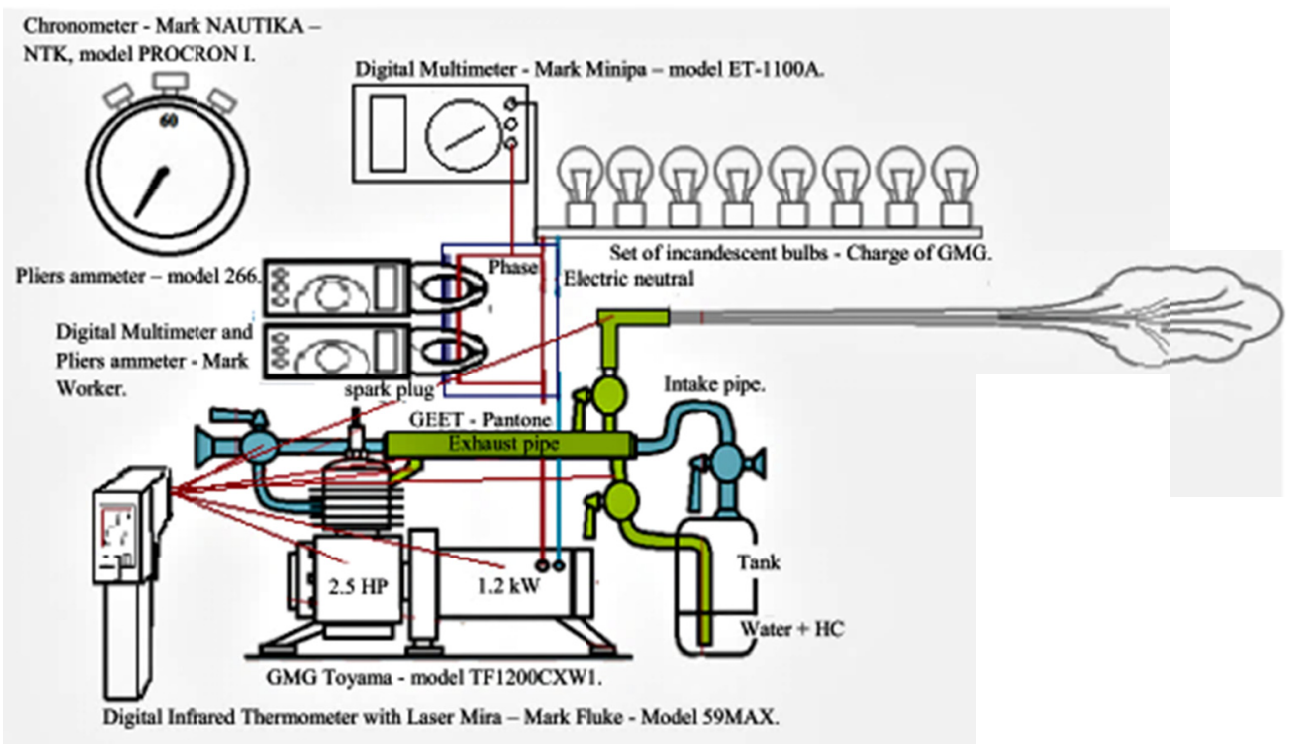

Figure 11. Schematic drawing Scenario 2: assay with the GEET-Pantone reactor

For Scenario 2, a single test was performed for the nominal load of $560 \mathrm{~W}$, with two replicates (called, in this work, Test 1 and Test 2). The total initial volume of the mixture was $500 \mathrm{~mL}$, being approximately $157 \mathrm{~mL}$ of ordinary (non-additive) gasoline, which corresponded to $114.61 \mathrm{~mL}$ of pure gasoline plus $42.39 \mathrm{~mL}$ of anhydrous alcohol $(99.6 \%$ purity), which were added to $343 \mathrm{ml}$ of potable water. Once the initial data were collected, according to procedures already described, the same variables presented in Scenario 1 were measured every minute, in a total of 5 minutes per test.

Figure 12 shows the layout and identification of GEET-Pantone constituent elements, characterized by control valves ( $1 / 4$ turn register), control valves (drawer registers), reservoir/bubbler, cooling system radiator reservoir, plus some of the measurement equipment used during the tests.

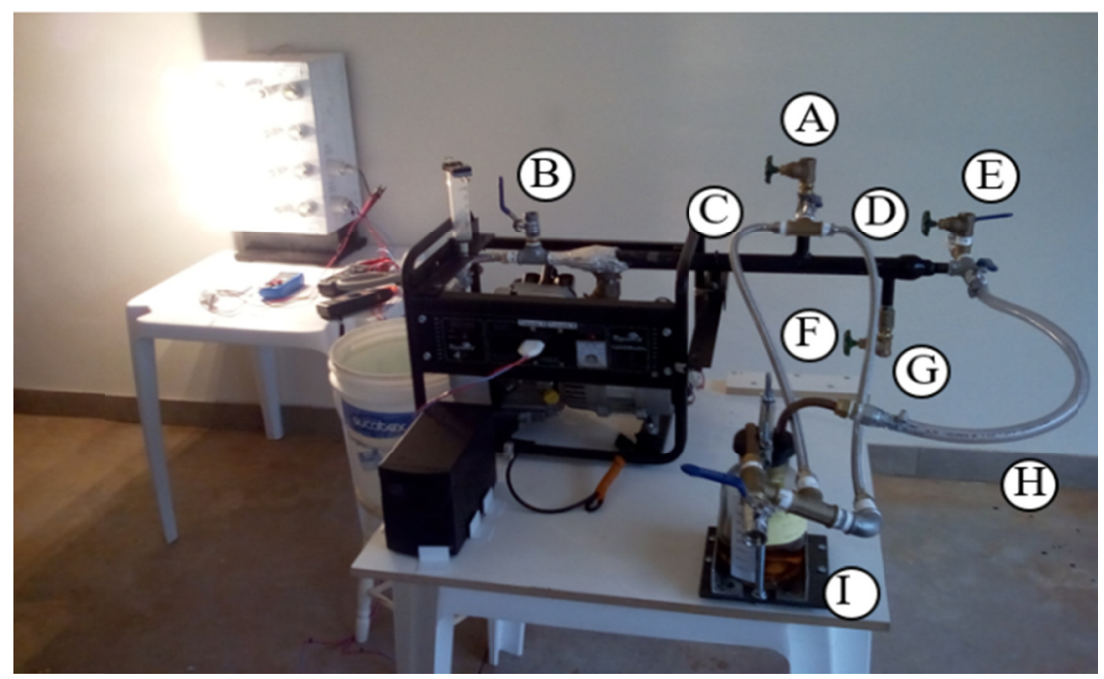




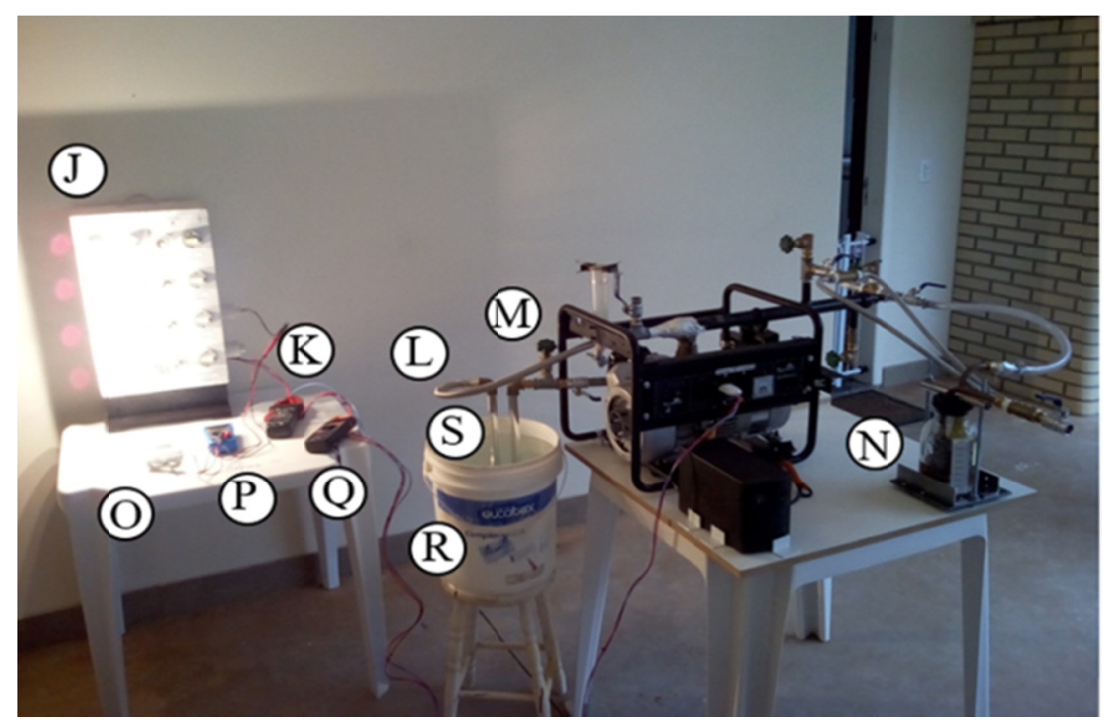

Figure 12. Test configuration with load of GMG-GEET-Pantone

Note. (A) Control valve (1/2-inch drawer registration) for adjusting the volume of gases in the mixing/bubbler tank (exhaust duct 1); (B) Control Valve (1/4 turn of 1/2-inch) air/fuel mixture (post-combustion chamber); (C) Exhaust gas duct 1 for the mixing/bubbler reservoir (1/2-inch flexible hose with stainless steel mesh for hot water); (D) Duct 2 of the exhaust gases for the mixing/bubbler reservoir (1/2-inch flexible hose with stainless steel mesh for hot water); (E) Control valve (1/2-inch drawer log) of the air/fuel mixture (gas and steam) from the mixing/bubble reservoir (pre-reactor); (F) Control valve (1/2-inch drawer log) of exhaust gas flow (exhaust 2); (G) Rigid outlet pipe of the mixing tank/bubbler (gas and vapor fuel); (H) Flexible duct (flexible pressure hose-mesh of 250 psi per 1/2-inch) interface (g) with (e); (I) Maneuver valve (1/4 turn 1/2-inch) control of the vacuum in the mixing tank/bubbler; (J) Test lamps; (K) Digital Multimeter and Pliers ammeter-Mark Worker; (L) Duct (1/2-inch flexible hose with stainless steel mesh for hot water-9 $\mathrm{mm}$ ) fuel/oxidant inlet valve (n); (M) Control valve (1/2-inch drawer log) for fine tuning air/fuel mixture after intake radiator; (N) Mixing tank/bubbler $(800 \mathrm{~mL})$; (O) Thermohigrometer-Mark Incoterm-model 7666.02.0.00; (P) Digital Multimeter-Mark Minipa-model ET-1100A; (Q) Pliers ammeter-model 266 Clamp Meter; (R) Intake radiator reservoir (bucket with nominal capacity of $18 \mathrm{~L}$ ); (S) Radiator (1/2-inch aluminum tubing and standard brass fittings in hydraulic systems).

\section{Results and Discussion}

\subsection{Scenario 1: GMG Carbureted With Load}

Graph 1 presents the power $(\mathrm{kW})$ and consumption $(\mathrm{L} / \mathrm{h})$ ratio for the four (4) essays carried out $(70 \mathrm{~W} / 127 \mathrm{Vca}$, $140 \mathrm{~W} / 127 \mathrm{Vca}, 210 \mathrm{~W} / 127 \mathrm{Vca}$ and $560 \mathrm{~W} / 127 \mathrm{Vca}$, respectively). In all tests, common gasoline (73\% gasoline and $27 \%$ anhydrous alcohol) and the same volume $(60 \mathrm{~mL})$ were used. 


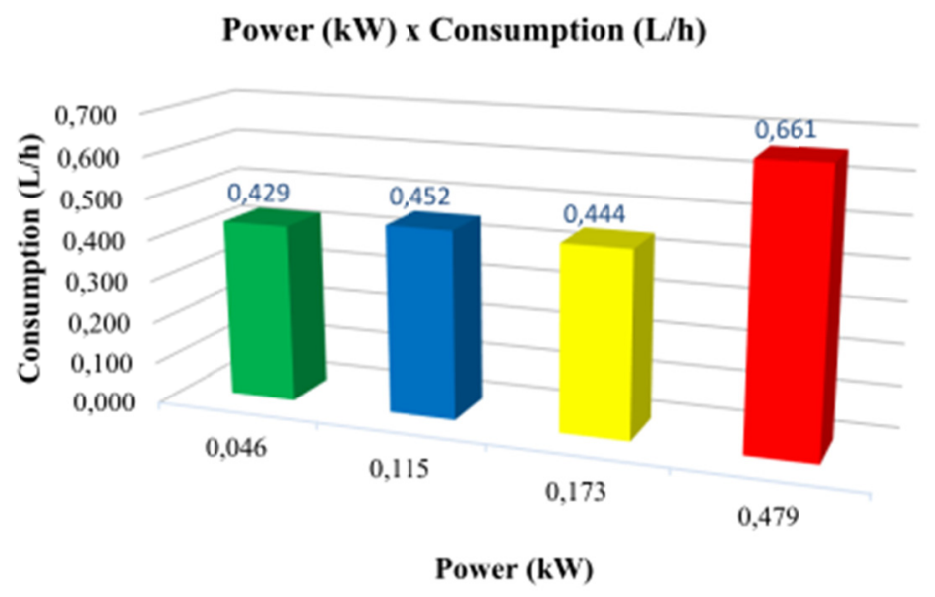

Graph 1. GMG carbureted with tests with load-Power $(\mathrm{kW}) \times$ Consumption $(\mathrm{L} / \mathrm{h})$

In this graph, when looking at the magnitude ratios plotted, it was clear that for a greater power supplied there is a direct relation in the increase of the demanded fuel consumption. However, comparing Test 3 with Test 4, Test 2 with Essay 3 and Essay 1 with Essay 2, it is found that, for smaller loads, the fuel consumption is higher. To demonstrate, assay 3 consumes, proportionally, $86.23 \%$ more fuel to generate the same $\mathrm{kW}$ as Test 4 .

Graph 2 relates to the Power $(\mathrm{kW})$ ratios with the specific Consumption $(\mathrm{g} / \mathrm{kWh})$ for the four (4) essays performed.

\section{Power (kW) x Specific consumption $(\mathrm{g} / \mathrm{kWh})$}

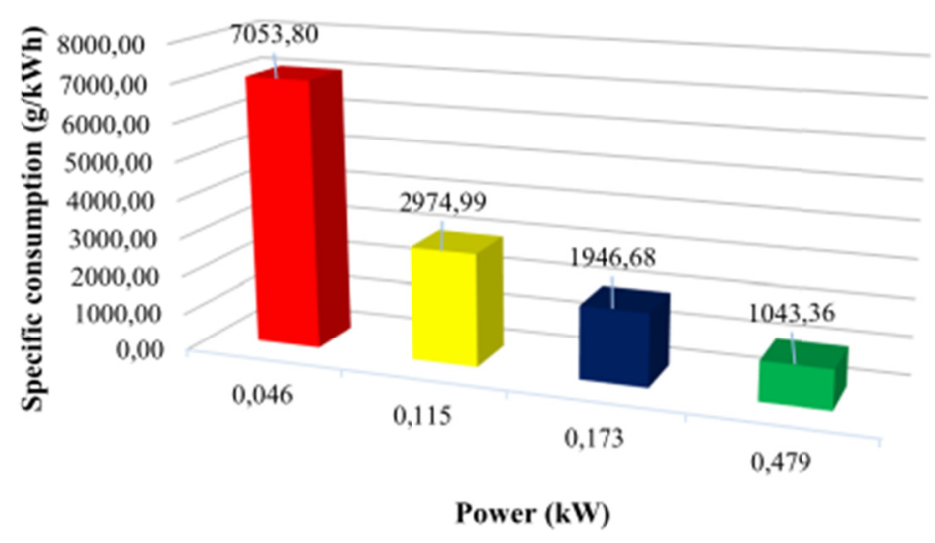

Graph 2. GMG carbureted with essays with load-Power $(\mathrm{kW}) \times$ Specific consumption $(\mathrm{g} / \mathrm{kWh})$

Considering that the specific consumption $(\mathrm{g} / \mathrm{kWh})$ refers to the efficiency of the engine to convert fuel into work, it can be objectively inferred that the Essay 4 is the most efficient in terms of the conversion of fuel into electric power useful for the loads considered in the respective experiments. On the other hand, Test 1 is the least efficient for the essays performed.

Graph 3, referring to GMG carbureted with the 4 (four) essays, shows the relation of Power $(\mathrm{kW}) \times$ Efficiency $(\%)$. 


\section{Power (kW) x Efficiency (\%)}

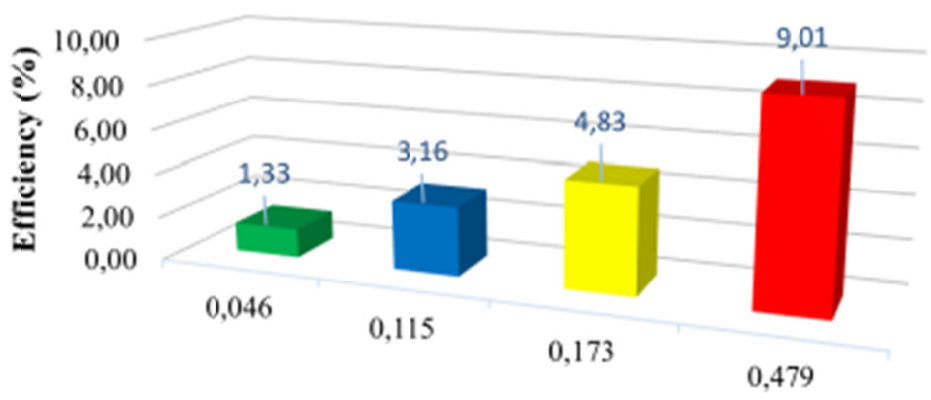

Power (kW)

Graph 3. GMG carbureted with load essays-Power $(\mathrm{kW}) \times$ Efficiency $(\%)$

Based on the relationships plotted, it is evidenced that the Essay 4 is the one that presents a better efficiency (\%) in relation to the power $(\mathrm{kW})$ generated. The Essay 1, on the other hand, is the one with the lowest efficiency (\%) in relation to the power $(\mathrm{kW})$ generated, and the other Essays ( 2 and 3 ) show proportionality in terms of the parameters analyzed. It was verified, therefore, that GMG presented a higher yield (\%) for a higher power value $(\mathrm{kW})$ demanded.

\subsection{Scenario 2: GMG With GEET-Pantone With Load}

O Graph 4, referring to GMG with GEET-Pantone coupled to a nominal load of $560 \mathrm{~W}(8 \times 70 \mathrm{~W} / 127 \mathrm{Vca})$, gas/water mixture ratio of 25/75, with the 2 (two) tests (repetitions) performed, has the following relation Test $\times$ Consumption $(\mathrm{L} / \mathrm{h})$ :

\section{Test $x$ Consumption $(\mathrm{L} / \mathrm{h})$}

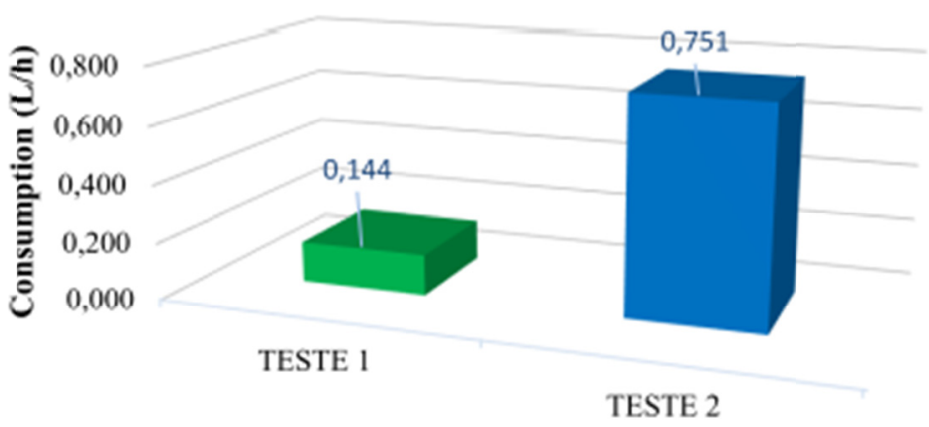

Test

Graph 4. GEET PANTONE and GMG with Load-Mix 25/75-Test $\times$ Consumption (L/h)

When analyzing Graph 4 , it is verified that Test 1 presented a lower proportional consumption $(0.144 \mathrm{~L} / \mathrm{h})$. It is assumed in this Test that part of the initial volume of water was converted into a fuel equivalent, or simply allowed the entry of atomized water into the combustion chamber, increasing the efficiency of the system by increasing the compression ratio, and possible cooling of the combustion chamber.

Graph 5 shows the relation Test $\times$ Specific consumption $(\mathrm{g} / \mathrm{kWh})$ for the same tests performed. The graph indicates that Test 1 was the most efficient, with a specific consumption of $253.91 \mathrm{~g} / \mathrm{kWh}$, and Test 2 was less efficient, with a specific consumption of $988.73 \mathrm{~g} / \mathrm{kWh}$, confirming the results presented in the graph previous. 


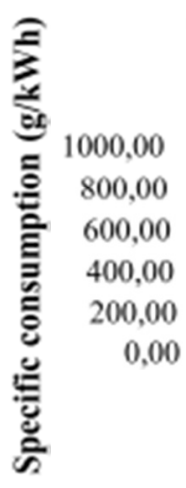

\section{Test $x$ Specific consumption $(\mathrm{g} / \mathrm{kWh})$}

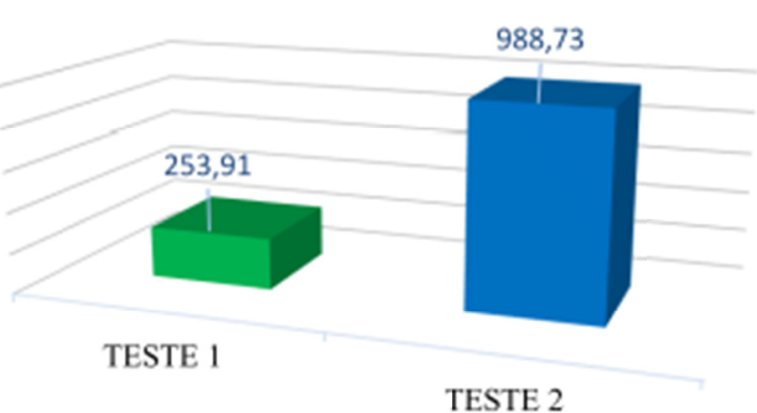

Test

Graph 5. GEET PANTONE and GMG with Load-Mixture 25/75-Test $\times$ Specific consumption $(\mathrm{g} / \mathrm{kWh})$

Graph 6 presents the relation Test $\times$ Efficiency (\%) for the same tests performed. The values plotted again indicate that Test 1 was the most efficient (32.82\% efficiency), and Test 2 was the least efficient $(8.43 \%$ efficiency). Further tests should be performed to re-evaluate these results, and to seek a better understanding of the physicochemical phenomena that occurred during the same.

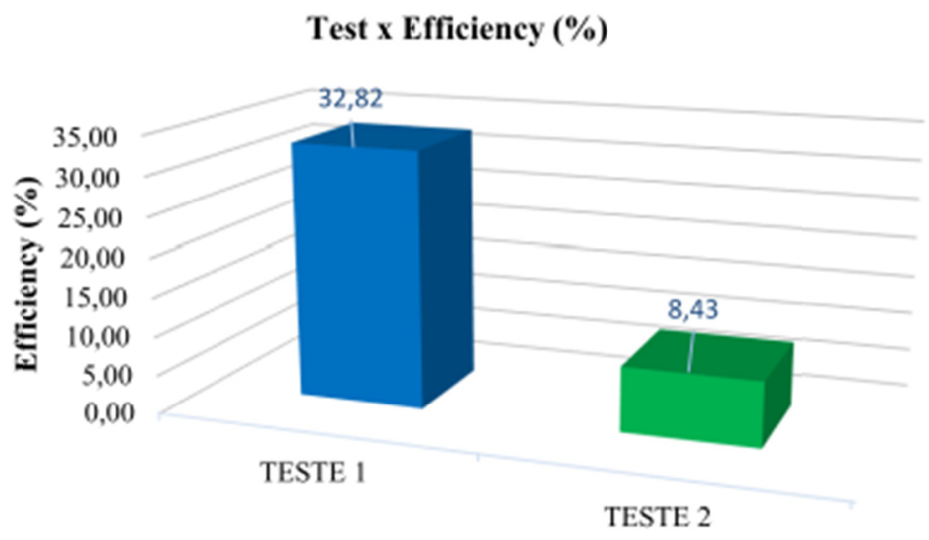

Test

Graph 6. GEET PANTONE and GMG with Load-Mix 25/75-Test × Efficiency (\%)

\section{Conclusions}

It was possible to verify, in this work, the behavior of a GMG, with $2.5 \mathrm{HP}$ gasoline engine, submitted to two fuel supply and control technologies. In the case of the conventional essays, with original carburetor, what was verified is that the engine presented, even with small instabilities, functional behaviors within the expected for this type of configuration. It was verified that, for higher load values, the set tends to be more efficient, with proportional reduction of the consumption $(\mathrm{L} / \mathrm{h})$ of fuel per $\mathrm{kW}$ generated.

As for the tests performed with the GMG equipped with GEET-Pantone, in a mixture of $25 \%$ of pure gasoline and $75 \%$ of water, some inconclusive results were verified. In the first test, an efficiency of $32.82 \%$ was obtained, well above the efficiency presented by the carburized system, for the same load conditions $(9.01 \%)$. In the second test, an efficiency of $8.43 \%$ was obtained, slightly below that presented in the carburized system, and well below the efficiency presented in the previous test. In this context, more tests should be carried out, and other variables should be measured, such as $\mathrm{CO}, \mathrm{CO}_{2}$ and total non-ignited hydrocarbons in the exhaust gases, in order to obtain more information about the results obtained. 


\section{References}

Albuquerque, C. F., et al. (1976). O livro do automóvel. Seleções do Reader's Digest (6 th ed.). Lisboa: B\&D.

ANP (Agencia Nacional do Petróleo, Gás Natural e Biocombustíveis). (2016). Existe chumbo na composição da gasolina comercializada no Brasil? Retrieved from https://www.anp.gov.br/wwwanp/fiscalizacao-multas-eregularizacoes/247-perguntas-frequentes/consumidores/2712-existe-chumbo-na-composicao-da-gasolina-co mercializada-no-brasil

Antonini, N. A. (2000). Projeto e construção de motores de combustão interna de êmbolo rotativo (Dissertação para obtenção do Título de Mestre em Engenharia, Programa de Pós Graduação em Engenharia Mecânica, Universidade Federal do Rio Grande do Sul, Porto Alegre). Retrieved from file://C:/Users/Seven/Desktop/ DISSERTA\%C3\%87\%C3\%83O\%20-\%20APOIO/000295528\%20-\%20MOTORES\%20ROTATIVOS.pdf

Brown, L. S., \& Holme, T. A. (2009). Química geral: Aplicada à engenharia (1st ed.). São Paulo: Cengage Learning.

Daniels, B., \& Daniels, A. (2007). Automotive illustrators. Accord 3.0 VTEC cutaway engine illustration. Retrieved from http://www.automotive-illustrations.com/engines.html

Fogaça, J. R. V. (2016). Combustiveis renováveis por meio da pirólise. Brasil, Escola. Retrieved from https://brasilescola.uol.com.br/quimica/combustiveis-renovaveis-por-meio-pirolise.htm

Hennessy, K. (2011). O livro do carro: enciclopédia visual. São Paulo: Editora Globo.

Henry, D. (2011). 100\% hydrogen conversion: For autos, trucks, SUVs (1st ed.). Future Energy Concepts, Inc.

Hinrichs, R. A., Kleinbach, M., \& Reis, L. B. (2010). Energia e meio ambiente (4th ed.). São Paulo: Cengage Learning.

Homa, J. M. (2009). Aeronaves e motores: Conhecimentos técnicos (29th ed.). São Paulo: ASA-Edições Gráficas Ltda.

Kouropoulos, C. P. (1998). The GEET Demystified. Retrieved from http://rexresearch.com/pantone/pantone. htm\#usp

Lovins, A. B. (2013). Reinventando o fogo: Soluções ousadas de negócios na nova era da energia (1st ed.). São Paulo: Editora Cultrix.

Martz, C. (2001). Elaboration d'unbanc d'essaiet caractérisations du procédé GEET de P. Pantone à reformage. Projet de Fin d'Etudes Génie Mécanique option Energétique Industrielleré alisé à l'ENSAIS, Institut National Des Sciences Apliquées (INSA), Strasbourg, France. Retrieved from http://www.econologie.com/ file/restricted/Rapport_complet_publie.pdf

Munsey, A. (2016). Directory: GEET reactor by Paul Pantone. Retrieved from http://peswiki.com/ directory:geet-reactor-by-paul-pantone

Naudin, J. L. (2005). Tests of a lawn mower retrofitted with the Multi-Fuels Processor (PMC). Retrieved from http://jlnlabs.online.fr/bingofuel/pmcjlnen.htm

Steam Engine Operation. (2016). How Steam Engines Work. How Stuff Works-Science. Retrieved from $\mathrm{http}: / /$ science.howstuffworks.com/transport/engines-equipment/steam1.htm

Toyama. (2016). TF1200CXW1. Toyama, Brazil. Retrieved from http://www.toyama.com.br/?menu=produtos\& produto $=. \& \operatorname{cod}=235$

Zuffo, J. A., \& Wolff, M. M. (1990). Eletrônica: Passo a passo (Vol. 3). São Paulo: Nova Cultural Ltda.

\section{Copyrights}

Copyright for this article is retained by the author (s), with first publication rights granted to the journal.

This is an open-access article distributed under the terms and conditions of the Creative Commons Attribution license (http://creativecommons.org/licenses/by/4.0/). 